\title{
TRANSONIC AXIAL COMPRESSOR ACTIVE BOUNDARY LAYER CONTROL CONCEPT AND ITS EVALUATION
}

\begin{abstract}
The article presents a concept of boundary layer control in transonic axial compressors. Two methods for obtaining boundary layer control are presented. It is proposed that by combining those two methods, an efficient way of preventing turbulent boundary layer separation in transonic compressor passages can be obtained without the loss of the compressor flux. The concept, is based on the idea of removing boundary layer flows at one stage, and using this removed flux as a blowing type boundary layer control, at previous stage where lower pressures occur. This creates a loop of secondary flow between those stages preventing the boundary layer separation (especially the shock induced separation) on both stages. Two dimensional numerical analyses are performed to assess the possible passage performance (especially the diffusion factor). On the basis of two dimensional analyses, the possible performance of such compressor stage is estimated. The aerodynamic possibility of greatly increasing the axial compressing stage loadings and pressure ratios without increasing blade velocities and passage flow Mach numbers is shown. This possibility has a growing importance as the overall pressure ratio of turbojet engines and tends to rise with every next engine generation. Main conclusions are drawn, showing the possibilities for further research in the scope of this concept.
\end{abstract}

Keywords: flow separation, transonic diffusers, turbojet engines,

\section{State of the art and motivation}

\subsection{State of the art transonic compressors in modern jet engines}

Vast majority of modern jet engines, generates their overall pressure ratio, by axial compressor operation. Because the pressure ratio generated on a single compressor stage is insufficient for efficient engine operation, compressors in use are multistage compressors. Since first turbojet engines, the pursuance of stage pressure ratio enhancement takes place.

\footnotetext{
${ }^{1}$ Autor do korespondencji/corresponding author: Bartosz Ziegler, Poznań University of Technology, ul. Piotrowo 3, 60-695 Poznań, e- mail: bartosz.ziegler@ doctorate.put.poznan.pl
} 
Achieving high pressure ratios makes it possible to build an engine with high overall pressure ratio utilizing compressor of reasonable number of stages. The Changes of average pressure ratio per compressor stage is shown on figure 1, separately for high bypass turbofans typical for commercial airliners and low bypass military turbofans typical for multirole fighter aircrafts. From third order polynomial trend lines on the plot, one can see, that in both engine types there's a continuous trend of increasing the pressure ratio per stage. This pursuance led to the development of transonic compressors, in which, relative flow velocities in blade-to-blade passages are supersonic at passage inlet and decrease to subsonic values before passage outlet. Higher the inlet relative Mach number, and velocity drop in the passage, higher the pressure rise in the channel. In passages of such compressors the highest pressure rise occurs on a normal passage shock positioned between the compressor blades (see figure 2). This shock, being an effective way of flow compression, creates a region of very high adverse pressure gradient. Near passage walls, such pressure gradient causes the boundary layer flow to turbulently separate (also shown on figure 2).

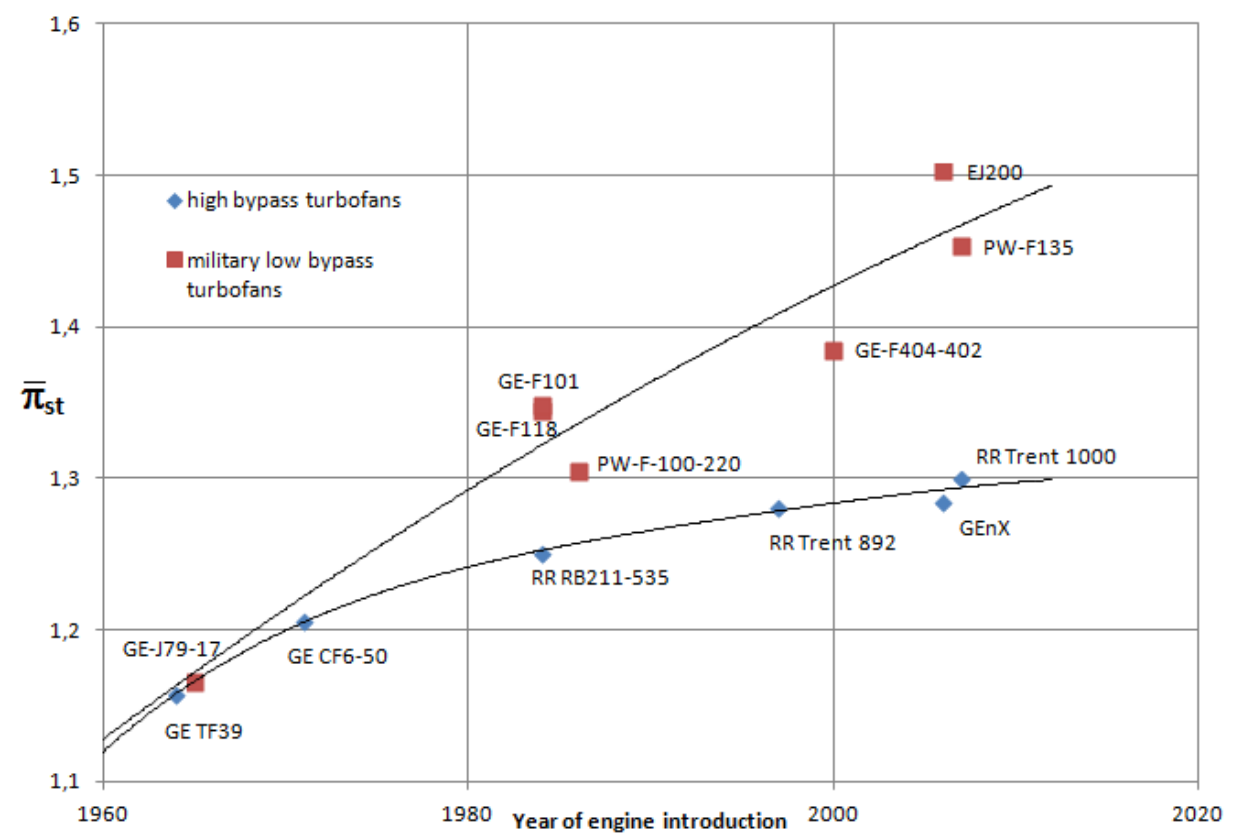

Fig. 1. Changes of average jet engine stage pressure ratio in past years. Black lines are third order polynomial trend lines for both engine types 


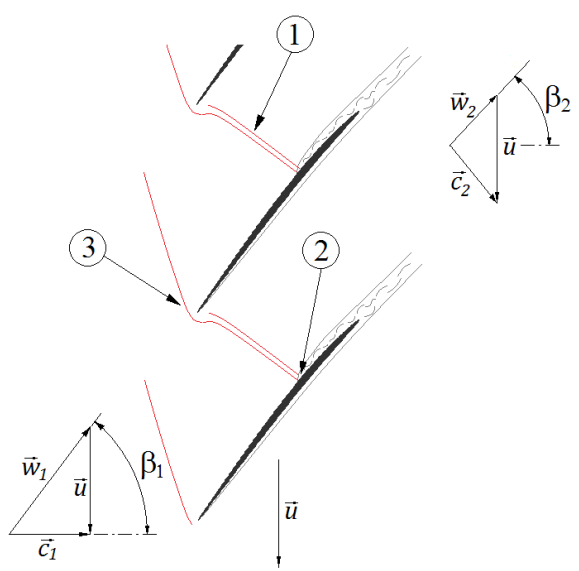

Fig. 2. Typical flow topology of a transonic compressor cascade: 1 - passage shock (a normal shockwave slowing the flow down from supersonic to subsonic range), 2 - shock foot on the blade suction side, the place most prone to flow separation (so called shock induced separation), 3 - shock created by an airfoil leading edge

\subsection{Work motivation}

Transonic compressors are in wide use now for more than a decade. Efforts done in their development allow to steadily increase their performance. The potential pressure ratio, that can be achieved depends mainly on the kinematics of the working channel flow, since the potential (isentropic) total pressure ratio of a stage can be written as:

$$
\pi_{i s}=\left(\frac{T_{02}}{T_{01}}\right)^{\frac{\kappa}{\kappa-1}}=\left(\frac{h_{01}+l_{s t}}{h_{01}}\right)^{\frac{\kappa}{\kappa-1}}
$$

Where: $T_{01}, T_{02}-$ total temperatures at the working channel inlet and outlet, $\kappa$ - heat capacity ratio of the gas, $h_{01}, h_{02}-$ total enthalpies at the working channel inlet and outlet respectively, $l_{s t}$ - specific work input to the gas.

As can be seen from equation 1, the only way to increase the pressure ratio attainable from a single compressor stage (at given inlet parameters) is to increase its work. Since real flows are never isentropic, real pressure ratios are always somewhat smaller than those resulting from equation 1 . The specific work input, can be determined by the specific power of the rotor, being the product of working cascade velocity and specific force (being the rate of specific momentum change). For a simplified 2D flow like presented on figure 2, this work can be written as:

$$
l_{s t}=\vec{u} \cdot\left(\vec{w}_{2}-\vec{w}_{1}\right)=u\left(w_{2} \sin \beta_{2}-w_{1} \sin \beta_{1}\right)
$$

Where: $u$ - working cascade velocity, $w_{1}, w_{2}-$ flow relative velocities at working channel inlet and outlet respectively, $\beta_{1}, \beta_{2}$ - relative flow angles at working channel inlet and outlet respectively (see figure 2 ). 
Usually, in transonic compressors the cascade relative flow inlet parameters are limited by structural strength of the rotor and reasonable flow Mach numbers (high Mach numbers cause inadmissible total pressure losses on shocks). Hence the possibility of increasing the stage work is focused mainly on the reduction of relative outlet velocity and flow angle. Ability of the channel to slow the flow can be somehow characterized by simplified form of a diffusion factor - DF:

$$
D F=\frac{w_{\max }-w_{2}}{w_{1}}
$$

Where: $W_{\max }-$ maximum relative velocity in the passage, $W_{1}, W_{2}-$ flow relative velocities at working channel inlet and outlet respectively.

In transonic axial compressor increasing DF is very hard to do, because the high adverse pressure gradients make flow prone to separate from the blade. Separated flow cannot be effectively slowed down, nor can it effectively change direction. A strong separation in a high turning passage flow, leads to compressor stall preventing it from operating at all. To allow for higher flow turning angles and more diffusion (compressing the gas by slowing it down) in the channel, the boundary layer separation phenomenon has to be eliminated or at least controlled. A study taken by MIT Gas Turbine Laboratory [1] showed that, in fact preventing the flow separation by active boundary layer control allows to roughly double the compressor stage work. The designed, built and tested in this study single stage compressor unit, demonstrated total pressure ratio of 3.17 at around $78 \%$ efficiency at $100 \%$ rotational speed and partial loading. At lower speeds, higher efficiencies (up to 89\%) were recorded. The tested compressor stage utilized a set of slots in the flow channel that removed the boundary layer flows (so called boundary layer bleeding). It was also shown, that the compressor designed for such high loadings is unable to operate without the boundary layer bleeding. After closing the bleeds the compressor stalled immediately, and was unable to recover from stall without bleeding restored (regardless the value of applied back pressure) [1]. Some other studies [2-4] showed also the possibility of boosting axial compressor performance by the removal of boundary layer flows in regions prone to flow separations. The problem with controlling boundary layer flows by bleeding is the removal of few percent of flux on each stage. Doing this on a multistage compressor would significantly reduce the compressor output flux, hence also the engine power and efficiency. The concept being an object of this article, aims into overcoming that issue.

\section{Proposed concept}

Boundary layer bleeding seems to be the most effective known method for preventing boundary layer separation (especially the shock induced separation). It was utilized since decades in supersonic air inlets (which similarly as com- 
pressor passages are examples of transonic diffusers). The mechanisms of bleed interaction with compressible flows are therefore well known.

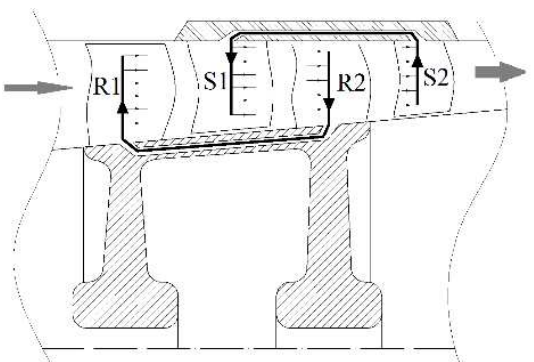

Fig. 3. Scheme of proposed boundary layer flow control arrangement on two adjacent compressor stages. The working channel of subsequent stage (R2) is controlled by the boundary layer removal, the bled air is then used as blowing medium on preceding stage working channel R1. Same with stationary channels (S2 and S1).

There are however similar techniques of active boundary layer control, one of which is the blowing boundary layer control. The main argument for the introduction of this method, is that it could theoretically utilize as a blowing medium the air removed in passages controlled by boundary layer bleeding. Connecting those two methods for boundary layer control, on two stages of a compressor would not only eliminate the flux loss, but also eliminate the need of providing auxiliary channels and aperture carrying the bled medium out of the compressor. Scheme for proposed arrangement of boundary layer control on two adjacent compressor stages is shown on figure 3. A challenging task in such arrangement, is to establish an effective way of preventing flow separation by blowing, with limited pressure of used medium. The method has to be sufficiently effective to manipulate boundary layer with only the overpressure created between stages and decreased by the losses in the auxiliary channel connecting the stages.

\section{Preliminary 2D working passages design}

Two dimensional geometries for both working passages were designed and steady state analysis with ANSYS Fluent code was performed. Preliminary designs, showed that the most effective arrangement of blowing slots is to use two slots, oriented streamwise, one before the intended position of passage shock and one after that position. First one, having smaller throat is used to reaccelerate boundary layer flow before it meets the passage shock, thus preventing shock induced separation. The second one, was used to allow for possibly high further deceleration of the flow. The turning angle of the cascade is not so big (roughly $18^{\circ}$ ) this is due to the fact that in two dimensional cascade flows, the outflow relative Mach number is directly dependent on the outflow angle. So to slow the flow down to around $\mathrm{M}=0.4$ in two dimensions the turning angles are quite small (in 3D rotor cascade, the channel span is decreasing so for the same area ratio a much higher turning angle is obtainable). The later stage has two bleeding slots. 

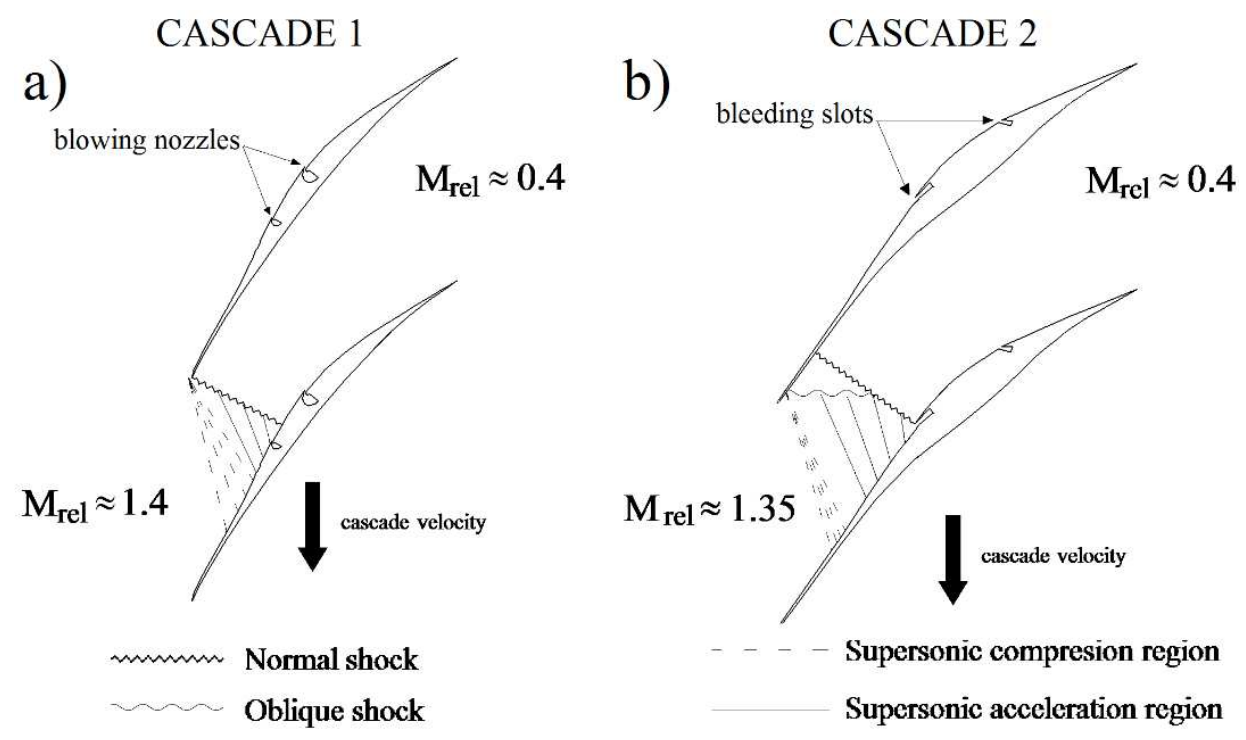

Fig. 4. Geometries and anticipated flow topologies for two dimensional cascades. The blowing controlled working cascade - a) and bleeding controlled working cascade of later stage $-b$ )

Main, with a sharp leading edge, positioned in the place of intended passage shock foot. This kind of bleed geometry is based on the geometry of so called shock trap bleed used in supersonic air inlets of turbojet engines. As the name suggests, this kind of bleed aside of removing boundary layer has also the ability to stabilize passage shock position. Both geometries are shown with anticipated supersonic flow topologies at figure 4 . The plenum for blowing and bleeding medium inside the blades is not included in the two dimensional model. Both passages were meshed using ANSYS ICEM software what allowed for creation of high quality, quadrilateral meshes matched to the anticipated flow topology (mainly alignment with the flow and higher resolutions in boundary layer regions and near anticipated shock position). Analysis were made for total pressure - inlet boundary condition and static pressure - outlet boundary condition. In the case of blowing controlled channel, the k- $\omega$-SST turbulence model was used as believed to be the most accurate 2 equation model for flow separation prediction. In the case of bleeding controlled channel, with k- $\omega$-SST the solution didn't tend to converge when the shock foot was near the bleed. Convergence for second channel was finally achieved with the use of SpalartAllmaras turbulence model. On figure 5, contours of relative Mach number can be seen for both cascades. On the figure 5 also dimensionless (in relation to the total inlet pressure of the first cascade) relative total pressures of boundary control flows are given. 
a)

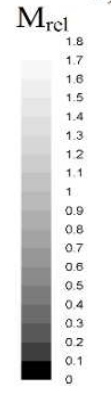

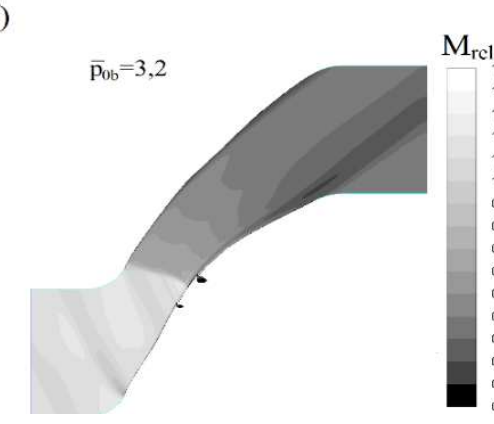

b)

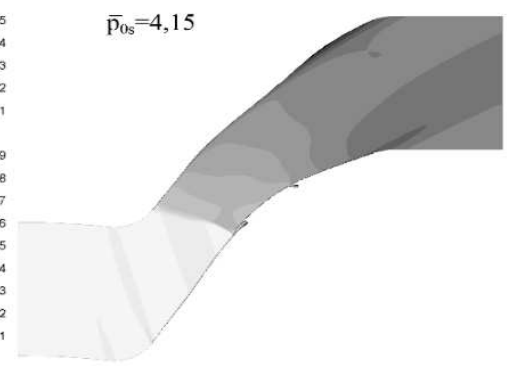

Fig. 5. Mach number contours in moving frame for blowing controlled stage working channel $-\mathrm{a}$ ) and bleeding (suction) controlled stage working channel $-\mathrm{b}$ ).

Although the stationary channel connecting those two was not modelled, the inlet parameters of the second cascade are taken from the outlet of the first one (with 3\% loss of total pressure to approximate for the pressure loss in stator passage). This was done to show, that the relation in pressures between cooperating stages can be sufficient for proposed boundary layer control arrangement. It can be noted, that the medium injected into the blowing controlled stage can have significantly lower total pressure than the medium removed from later stage. This gives some margin for the losses in auxiliary channel connecting the stages. Performance of both channels can be seen in table 1 .

Table 1. Parameters of both cascades obtained in the numerical analysis

\begin{tabular}{|c|l|l|}
\hline Parameter & \multicolumn{1}{|c|}{ Cascade 1 } & \multicolumn{1}{|c|}{ Cascade 2 } \\
\hline Chord based Reynolds number $-\mathrm{Re}_{\mathrm{C}}$ & $8,4 \times 10^{6}$ & $9,0 \times 10^{6}$ \\
\hline total pressure ratio - TPR & 3,02 & 2,53 \\
\hline Channel pressure recovery ratio - PRR & 0,951 & 0,980 \\
\hline Bleeding/blowing flux fraction & $3,24 \%$ & $3,72 \%$ \\
\hline Diffusion factor - DF & $1,15(0,76)^{*}$ & 0,78 \\
\hline Loading $\psi=\Delta h_{0} / u^{2}$ & 0,830 & 0,862 \\
\hline
\end{tabular}

* The jets injected into the channel achieve locally very high velocities, hence high $\mathrm{w}_{\max }$, the value in brackets gives the DF calculated with exclusion of that injection region, which gives more feasible information about main channel work.

\section{Conclusions}

Conducted study which elements are adduced in this article, showed the possibility of creating compact and efficient flow arrangements achieving boundary layer control on two adjacent highly loaded transonic compressor stages. The proposed method could allow for significant improvement in transonic passages diffusion factors, without the need of wasting the compressor 
flux and providing external apertures for bled air removal. It should be also noted, that channels shaped in three dimensions could achieve higher flow turnings with smaller diffusion factors. This create chance to achieve even higher cascade loadings than presented, or allow for simpler single point boundary layer blowing/bleeding arrangements in the blade to blade passage.

\section{Reference}

[1] Kerrebrock J. : Final Technical Report on AFOSR Grant F49620-98-1-0493 entitled RESEARCH AND DEVELOPMENT ON ASPIRATED COMPRESSORS, Gas Turbine Laboratory Department of Aeronautics and Astronautics MIT, Cambridge 2003.

[2] Epstein A. et al. : Final Technical Report on AFOSR Grant F49620-03-1-0309 entitled ASPIRATED HIGH PRESSURE COMPRESSOR, Gas Turbine Laboratory Department of Aeronautics and Astronautics MIT, Cambridge 2006.

[3] Knapke R.D., Turner M.G.: Detailed Unsteady Simulation of a Counterrotating Aspirated Compressor with a Focus on the Aspiration Slot and Plenum, Int. J. Rotating Machinery, 2013, Article ID 857617.

[4] Colombo E. et al.: Investigations on axial compressor cascades with aspiration on blades and hub, European Workshop on New Aero Engine Concepts, Munich 2010.

\section{KONCEPCJA KONTROLI WARSTWY PRZYŚCIENNEJ W SPRĘŻARKACH TRANSONICZNYCH I JEJ EWALUACJA}

\section{Streszczenie}

Artykuł prezentuje koncepcję dwóch metod kontroli warstwy przyściennej w kanałach transonicznych sprężarek. Zaproponowano aby przez połączenie tych dwóch metod, skuteczny sposób zapobiegania turbulentnego oddzielenia warstwy granicznej w transonicznych kanałach sprężarek można uzyskać bez straty strumienia sprężarki. Koncepcja opiera się na idei usuwania przepływów w warstwie brzegowej w jednym etapie oraz wykorzystaniu strumienia jako kontroli warstwy brzegowej we wcześniejszym etapie, gdy występuje niższe ciśnienie. To tworzy wtórną pętlę przepływu pomiędzy tymi etapami uniemożliwiających rozdzieleniu warstwy granicznej (zwłaszcza rozdzieleniu wywołanemu wstrząsem) na obu etapach. Dwuwymiarowa analiza numeryczna została przeprowadzona $\mathrm{w}$ celu oceny możliwej wydajności przejściowej (zwłaszcza współczynnika dyfuzji). Na podstawie dwuwymiarowej analizy określono możliwość wykonania takiego stopnia sprężarki. Przedstawiono aerodynamiczną możliwość znacznego zwiększenia obciążeń stopnia sprężania osiowego i wskaźników ciśnienia bez zwiększania prędkości łopat i liczb Macha podczas przepływu. Możliwość ta ma coraz większe znaczenie jako wskaźnika całkowitego ciśnienia silników turboodrzutowych i wykazuje tendencję do wzrostu w każdej następnej generacji silnika. Nakreślono główne wnioski, pokazując możliwości dalszych badań w tym zakresie.

Słowa kluczowe: separacja przepływu, dyfuzory transoniczne, silniki turboodrzutowe

DOI: 10.7862/rm.2014.16

Otrzymano/received: 15.05.2014

Zaakceptowano/accepted: 27.05.2014 